\title{
The Use of Non-Standard Indonesian Expressions by Men and Women in The Reader's Letters
}

\author{
Josefa J. Mardijono, Andrew Junarto \\ English Department, Faculty of Letters, Petra Christian University \\ Surabaya, East Java, Indonesia \\ e-mail: josefa@peter.petra.ac.id,_i03@yahoo.com
}

\begin{abstract}
This study reports on the non-standard Indonesian expressions used by men and women in The Reader's Letters in magazines. Seven editions of two different magazines, For Him Magazine and Cosmopolitan, were used as the source of data. The findings revealed the kinds of nonstandard expressions used by both gender, in terms of linguistic categories and non-standard features, also confirming that the men employed more nonstandard expressions than the women
\end{abstract}

Key words: non-standard Indonesian expressions, gender, kinds, frequency

In communication, people can use different varieties of the same language. The varieties can be either standard or non-standard. The language variety used is influenced by some factors in the social context, such as the age, status, topic, gender, and purpose (Alwi, Dardjowidjojo, Lapoliwa, \& Moeliono, 2003, p. 5). People who come from different social status, age, and gender use different varieties. The different use of language variety is usually reflected in the vocabularies and the language structure.

Based on gender, men and women are different, in terms of the language that they use (Holmes, 1992, p. 164). The different usage of language between men and women can be seen in many ways. Female speakers tend to use more "prestigious" form than male speakers in the same social background (Yule, 1997, p. 242). Lakoff (1978) states that women's speech is more "polite" than men's. Lakoff also claims that women tend to use hedges like "It's kinda nice" and question tags in expressing something like "The weather is really nice today, isn't it?" On the other hand, fillers and question tags are rarely found in men's language. Another clear difference between men and women's language is that women use "hyper-correct grammar". It means that women tend to use standard language. 
The use of different language varieties in society can be seen in daily life, in the spoken form and in the written one. Written language can be in the forms of newspaper, book, poster, booklet, and magazine. Among those kinds of written forms of language, magazine is one of the interesting written forms to be taken as the object of study. Magazine is a mass media in which several language varieties can be used. The language of magazine may be informal as the language should be as friendly as possible to the readers (Hadi, 2002). It should be communicative as it is more effective to achieve the target market. The communicative style of language that is used by magazine is almost the same as the spoken language style, which is usually less formal. However, as one form of written language, the language of magazine should be more explicit and clearer (Alwi et. al., 2003, pp. 7-8).

At the present time, there are magazines that are published especially for women readers and those published for men readers primarily. It shows that the needs of men and women in terms of information, interest, and entertainment are different. There are two magazines in the Indonesian language, which are designed for different gender: For Him Magazine (FHM) for male readers and Cosmopolitan for female readers. These two kinds of magazines have some common characteristics: The first similarity is on the content; both magazines are focused on the daily life. FHM concerns men's life, and Cosmopolitan concerns women's. The second similarity is that both magazines are under the same license, which is MRA-Media Group; both were first published in September 2003.

In order to study the language of men and women, one specific section of both kinds of magazines was chosen as the source of data, that is, the Reader's Letters. The letters posted by the readers are published and replied by the editors. The letters are mostly about compliments, requests, critiques, and opinions of the readers towards the magazines. Since FHM is a magazine whose readers are mostly men, the letters that are posted to be published in the readers' letters are also mostly written by men. On the other hand, the readers' letters of Cosmopolitan are usually written by women. As both magazines are monthly magazines, seven editions of each magazine, from September 2003 edition to March 2004 edition, were chosen as the source of data.

The language variety observed here are the non-standard expressions that are used by the women and men in composing their letters in the magazines. Expressions refer to all "linguistic forms" that are used in 
language (Crystal, 1997, p. 144). So, it is clear that expressions here can refer to all linguistic forms; "word, phrase, clause, and sentence" (Oda \& Suparno, 1994, pp. 25-28). Every language, including Indonesian, has its own expressions that have been regularized or standardized according to its own policy. Besides the standard Indonesian expressions, some other varieties are used. Riasa has found some characteristics of non-standard Indonesian expressions used in some teenagers' short story. Some of the characteristics are the use of non-standard affixes and the use of nonstandard terms. The expressions used by a speaker can also be nonstandard if the speaker uses foreign language instead of using the Indonesian language (Riasa, 2002).

In this study, the language used by the males and females, in terms of their use of non-standard expressions, was examined to find out the kinds of non-standard Indonesian expressions used by the writers in the Reader's Letters in the two kinds of magazines for different genders: For Him Magazine (FHM) and Cosmopolitan. The kinds of the non-standard expressions were classified based on linguistic categories and non-standard features. In addition, the study seeks to reveal the frequency of occurrence of the sentences containing non-standard expressions to find out whether the Indonesian male writers in the Reader's Letters in FHM used more non-standard Indonesian expressions than the Indonesian female writers in Cosmopolitan.

\section{Language and Gender}

Some linguists have done researches on the influence of gender on the language used. Lakoff, for example, has given some characteristics of women's language that differentiate them from men's. Women, as said by Lakoff, tend to use some forms that men rarely use. Some other linguists also discuss the reasons why men and women use the language in different ways (Montgomery \& Thomas, 1994). There are some reasons why both gender use the same language differently. One of the reasons is that sociologically women are usually more conscious to status than men. It can be related to the reality that in many societies, women are considered as the second class. Facing this reality, some women try to raise their status in the society. One of the ways is through the language they use. That is why women usually tend to use a more standard variation or "form" of language than men (Trudgill, 1974, p. 87). 
On the other hand, men usually tend to use more non-standard linguistic forms than women. It is influenced by the condition of men as a main part of working-class life. In many societies, men are the ones who have to work. The language that is usually used by the men is usually related to 'toughness'. Since 'toughness' is often considered as one of the characteristics of "masculinity", men tend to use the "working-class language", which is characterized by the non-standard form (Trudgill, 1974, p. 87).

Holmes also talked about the role of vernacular language in expressing masculinity. Men prefer "vernacular" forms as they carry "macho connotation" of "masculinity" and "toughness". This assumption, directly or indirectly, states that the standard forms of languages seem to be the females' languages (Holmes, 1992, pp. 174-175).

\section{Non-Standard Indonesian Expressions}

A non-standard variety is a language variety which has not been standardized and does not have official status. A language variety that does not suit the standard language norms is a non-standard language. Generally, it can be said that a dialect is a non-standard language (Tampubolon, 1978 p. 21). Non-standard language is usually the first language that is learned by people in a multilingual community, and the use of this kind of language is limited. This kind of language is usually used by people to show solidarity among those who come from the same group. This language is also sometimes used for everyday interaction or communication (Holmes, 1992, p. 81). The examples of the non-standard expressions that can be found in the Indonesian language are the Javanese language and the Jakartanese. Those kinds of language can also be called vernacular language. Based on the understanding that a standard language is the language that has certain norms not influenced by vernacular, regional, and foreign language, it can be said that the non-standard variety is the one influenced by those languages (Tampubolon, 1978, p. 23). In fact, people can choose which language they want to use to communicate. The use of other varieties, directly or indirectly, makes the standard language non-standard.

Riasa's study (2002) entitled "Bahasa ABG dalam Cerpen Remaja: Implikasi dan Pengajarannya bagi Siswa/i Sekolah Menengah di Australia" ("Teenager language in adolescent short story: Its implication and teaching 
to high school students in Australia") revealed the characteristics of the non-standard Indonesian, which were classified into nine types as follows:

1. An active verb + -in to form active transitive verbs Instead of using affixes "meN-kan" or "meN-i", people tend to use a simpler affix, which is "meN-in". For example: pikir $\rightarrow$ mikirin (think), ambil $\rightarrow$ ambilin (take).

2. Passive form 1: di- + simple verb + -in

This passive verb is formed by adding prefix "di-" and suffix "-in" into the simple verb. For example: jalan $\rightarrow$ dijalanin (go through).

3. Passive form $2: k e-+$ simple verb

This passive verb refers to passive form "ter" in standard Indonesian. For example: tangkap $\rightarrow$ ketangkap (catch), timbang $\rightarrow$ ketimbang (compared to).

4. Deletion of one or more letters

This can be in forms of the deletion of the first letter or phoneme or the deletion of the letter "h" from the standard Indonesian vocabulary. For example: habis $\rightarrow$ abis (ended), memang $\rightarrow$ emang (indeed).

5. Simplification or contraction of two different words

The examples are: terima kasih $\rightarrow$ makasih (thank you), bagaimana $\rightarrow$ gimana (how).

6. The use of other non-standard terms

The examples are: cantik $\rightarrow$ kece (pretty), dia $\rightarrow$ doski (he/she).

7. Substitution of one or more letters

The substitution is usually on the letter "a" to "e". For example: benar $\rightarrow$ bener (right), cepat $\rightarrow$ cepet (fast).

The substitution can also be in the forms of the changing of the dipthong "au" with "o" and "ai" with "e". For example: kalau $\rightarrow$ kalo (if), sampai $\rightarrow$ sampe (until).

8. Adaptation of foreign language.

For example: sorry $\rightarrow$ sori, comment $\rightarrow$ komen.

9. The use of foreign language

For examples: thank you, sorry.

Although this study was focused on the Indonesian teenagers' language, which is different from the subjects of this study, the Indonesian adults, the findings on the basic characteristics of the non-standard Indonesian is important for this study, to be applied as a guideline to identify and categorize the data. 


\section{METHDOLOGY}

In conducting the research, the writer used a qualitative descriptive approach dealing with mostly words as its main concern to find out the kinds of non-standard expressions used by men and women. Besides, the writer himself was the main instrument in collecting and analyzing the data gathered from the magazines.

The sources of the data of this research were seven editions of the two magazines, FHM (For Him Magazine) and Cosmopolitan, starting from September 2003 to March 2004. The data were nonstandard Indonesian expressions consisting of words, phrases, clauses and sentences.

\section{Data Collection and Data Analysis}

The data were collected by identifying the expressions that are nonstandard in Indonesian based on the non-standard guideline of Indonesian expressions. All the letters from the seven editions were put in a table, and the non-standard expressions were bolded. The table was also used to count the number of non-standard sentences and total number of sentences used in each edition. This was essential to count the frequency of occurrence of the non-standard expressions produced by the men and women writers.

Each non-standard expression collected was analyzed to determine its type based on linguistic forms and non-standard Indonesian features using Riasa's classification as a guideline, which means that it did not close any possibility to accommodate some other features of non-standard expressions. To view all the features of non-standard Indonesian expressions that occurred in both magazines, the results of both magazines were presented in one table for comparison.

To answer the question whether the men really used more nonstandard Indonesian expressions than the women, the frequency of occurrence of the non-standard expressions in both sources of data was counted based on the number of sentences containing non-standard expression(s) in relation to the total number of sentences produced in the letters in each edition, using the following formula:

$$
\frac{\mathrm{n}}{\Sigma \mathrm{n}} \times 100 \%
$$

$\mathrm{n} \quad=$ numbers of non-standard Indonesian sentences

$\sum \mathrm{N}=$ total number of sentences 


\section{FINDINGS AND DISCUSSION}

The whole findings were summarized in 4 (four) tables. Table 1 and Table 2 present the kinds of non-standard expressions, used in The Reader's Letters of FHM and Cosmopolitan respectively. Another table, Table 3 is used to summarize the types of non-standard features occurring both in the male magazine and the female magazine. Table 4 presents the frequency of occurrence of the non-standard expressions in the seven chosen editions of both kinds of magazines. Following the tables, explanation and discussions on the findings are provided.

\section{Kinds of Non-Standard Indonesian Expressions Used in FHM and Cosmopolitan}

The kinds of non-standard expressions in terms of the types of nonstandard features and the linguistic categories occurring in the male magazine, FHM, is summarized in Table 1.

\section{Table 1. Non-Standard Indonesian Expressions in FHM}

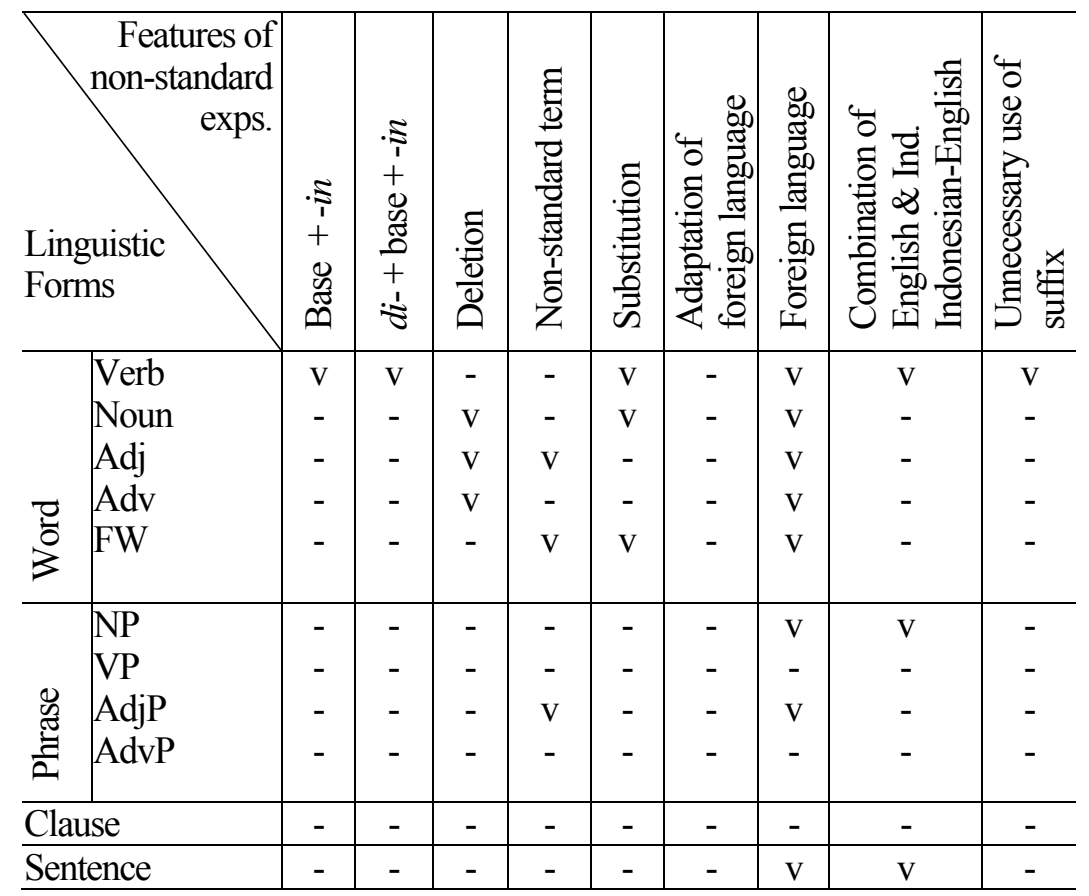


The check mark (v) indicates the existence of the kind of non-standard expressions in terms of linguistic category and type of non-standard feature; whereas the non-existence of the related kind is represented by a dash mark (-).

Table 1 shows the kinds of non-standard Indonesian expressions used by the male writers in FHM, categorized based on linguistic forms and types of non-standard features. Based on linguistic forms, the non-standard Indonesian expressions used by the male writers comprised words - verbs, nouns, adjectives, adverbs and function words --, and phrases - noun phrase, adjective and adverb phrase-, and sentences. The non-standard linguistic features found in the male writers' letters were categorized into eight types as follows:

a. base + -in

The non-standard suffix -in is usually used in Jakartanese to form a verb. It was found in malu-malu-in, used instead of the standard form memalukan. The suffix-in was attached to the stem malu (embarrassed), replacing the standard suffix -kan.

The stem was duplicated, while the prefix me- in the standard form was deleted.

b. $d i-+$ base + -in

The confix consisting of the prefix di- used in the standard Indonesian and the non-standard suffix -in was attached to the stem banding (compare) forming the non-standard passive verb form dibandingin (be compared), instead of using the standard Indonesian dibandingkan (be compared). Another example occurred in dikirimin (be sent), in which the prefix $d i$ and the suffix -in, forming the confix di-...- in was attached to the stem kirim (send). The non-standard suffix -in replaced the standard suffix $-i$ in the standard form dikirimi. From the examples it can be seen that the non-standard suffix -in could co-occur with the prefix di- forming a passive verb.

c. deletion

The element deleted could be a prefix or a letter used in the standard form, which existed in noun, adjective and adverb, as presented in the following examples:

kerjaan (job) : The prefix pe- in the standard verb form pekerjaan (job) has been deleted.

asik (fun) : The letter $y$ in the standard form of adjective asyik has been deleted.

aja : The standard adverb word is saja (only), in which the initial letter $s$ has been deleted. 
d. non-standard term

This type of non-standard feature occurs as adjective, function word, and adjective phrase, as seen in the following:

nglantur (confused)

nggak (not)

gaknorak (not vulgar)

The adjective nglantur does not exist in standard Indonesian. It is commonly used in Javanese vernacular. Similarly, the negation nggak and gak are from the same vernacular, Javanese, meaning not. They can be used interchangeably. In the data, nggak was used preceding a verb, i.e. nggak percaya (not believe), while gak was used preceding an adjective, i.e. gak norak (not vulgar)

e. substitution

Substitution occurs when a certain letter used in the standard form is replaced by another one. This type of non-standard feature typically occurs in Jakartanese in verb and noun, in which the letter $a$ is replaced by $e$, as shown in the following examples:

Verb : datang $\rightarrow$ dateng (come)

Noun : teman $\rightarrow$ temen (friend)

Another example was found in the use of function word the nonstandard function word kalo, which was originated from the standard form kalau. The letter $o$ representing the vowel [o] replaced the letters au representing the diphthong [au].

f. foreign language

This type of non-standard expressions occurred due to the use of foreign language, in this case, English, instead of the standard Indonesian expressions. It comprised words functioning as verb, noun, adjective, adverb, function word; phrases - noun and adjective phrases-, and sentences. The examples are presented in the following:

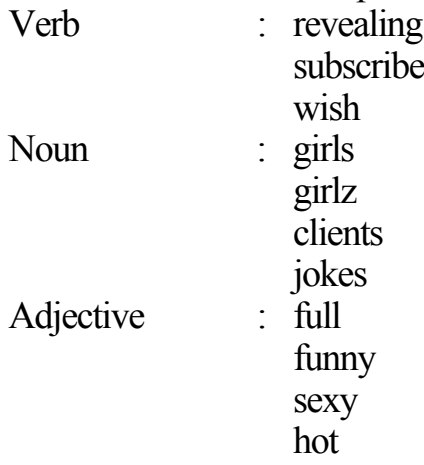




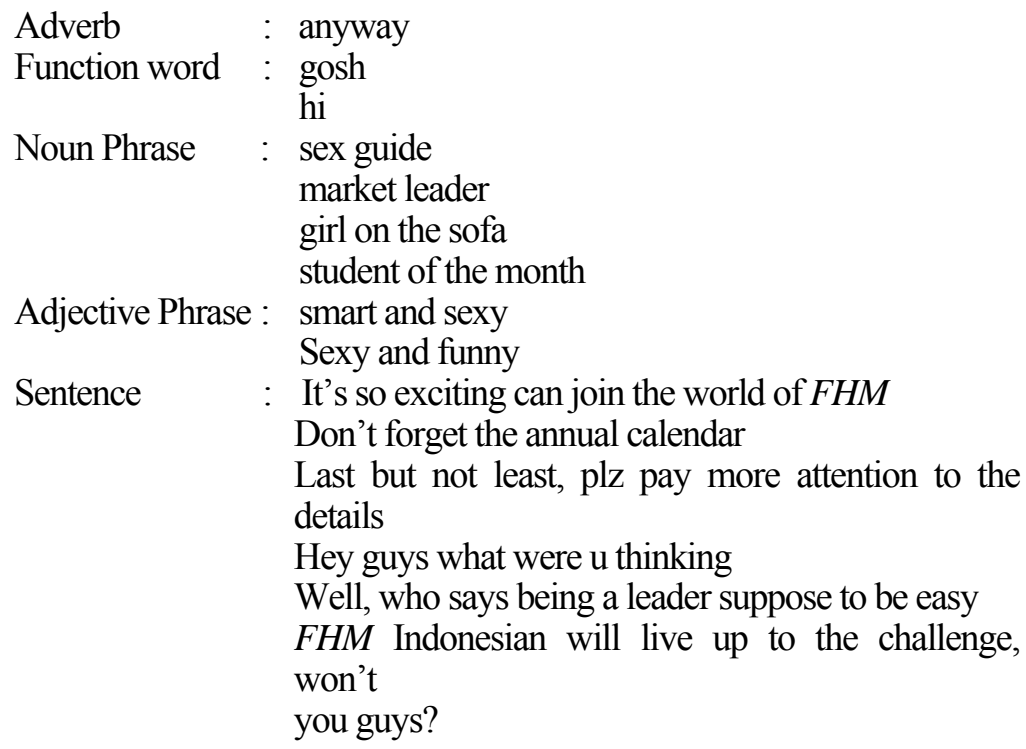

Some of the lexical words do not belong to the normal standard English, such as girlz, which was used instead of the standard form girls, plz instead of please, and $u$ instead of you. In addition there were grammatical deviations as found in the sentences: It's so exciting can join the world of FHM and Well, who says being a leader suppose to be easy

g. combination of English and Indonesian

Similar to the previous type, this type of non-standard expression was due to the use of the English language. The difference lies in the fact that the use of the English expression was mixed with the Indonesian prefix di- as found in the verb dirolling, in which the prefix -di was attached to the English stem rolling. In most cases, the Indonesian suffix denoting possessive, i.e., the first possessive form $-k u$ (my), the second possessive form - $m u$ (your), the third person possessive form nya (his/her), was attached to the English stem , which can be seen in the following nouns and noun phrases:

Noun

: Joke-nya

Cover-nya

Stress-ku

Noun Phrase : Local content-nya

beauty guide-mu

student of the month page-nya 
In the examples of noun phrase, the Indonesian suffix was attached to the English phrases local content, beauty guide and student of the month. In other cases, there was a mixture of Indonesian free morphemes combined with English free morpheme as found in the following:

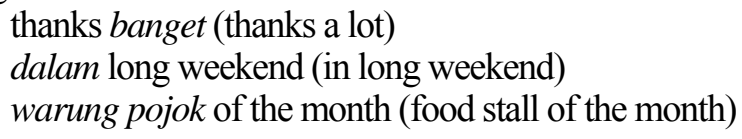

In one case the Indonesian function word, negation, bukan was inserted in the English sentence: Brand loyalty bukan (is not) taken for granted especially in this era of unlimited choice.

h. unnecessary use of suffix

There was one case occurring in the use of an Indonesian suffix -an attached to the standard verb form ganti (replace?) making a nonstandard term gantian. (take turns)

In the female magazine, Cosmopolitan, as shown in table 2, the nonstandard expressions comprised fewer linguistic categories compared to those found in FHM.

There were six linguistic categories consisting of noun, adjective, adverb, noun phrase, adjective phrase and sentence. The non-standard features found in the data could be classified into five types: non-standard term, adaptation of foreign language, foreign language, combination of English and Indonesian, and unnecessary use of suffix. The examples are presented in the following:

a. non-standard term

It was found in one case in the use of non-standard adverb malahan replacing the standard word bahkan (even)

b. foreign language

The foreign language used was borrowed from the English language, which were of various linguistic categories: noun, adjective, noun phrase, adjective phrase and sentence, as seen in the following:

Noun

: foreplay

website

thanks

trafficking

cover

Adjective : yummy

Noun Phrase : swimsuit special 
thanks a lot

tote bag

beauty guide

fun fearless female

the naked bartenders

Adjective Phrase : fun and fearless

Sentence

: Never let fear rule your life

You've helped me a lot

Your next target: get a pay rise

Table 2. Non-Standard Indonesian Expressions in Cosmopolitan

\begin{tabular}{|c|c|c|c|c|c|c|c|c|c|c|}
\hline \multicolumn{2}{|c|}{$\begin{array}{l}\begin{array}{r}\text { Features of } \\
\text { non-standard } \\
\text { exps. }\end{array} \\
\text { Linguistic } \\
\text { Forms }\end{array}$} & $\begin{array}{l}\cdot \tilde{T} \\
+ \\
+ \\
0 \\
\tilde{z} \\
m\end{array}$ & 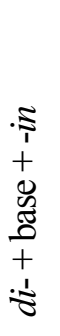 &  & 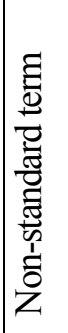 & 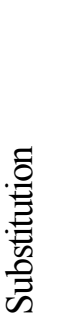 & 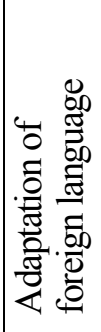 & 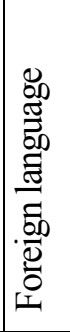 & 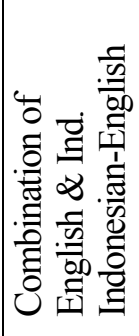 &  \\
\hline $\begin{array}{l}\overline{0} \\
\overline{3}\end{array}$ & $\begin{array}{l}\text { Verb } \\
\text { Noun } \\
\text { Adj } \\
\text { Adv } \\
\text { FW }\end{array}$ & $\begin{array}{l}- \\
- \\
- \\
- \\
-\end{array}$ & $\begin{array}{l}- \\
- \\
- \\
-\end{array}$ & $\begin{array}{l}- \\
- \\
- \\
-\end{array}$ & $\begin{array}{l}- \\
- \\
- \\
\mathrm{v}\end{array}$ & $\begin{array}{l}- \\
- \\
-\end{array}$ & $\begin{array}{l}- \\
\mathrm{V} \\
- \\
-\end{array}$ & $\begin{array}{l}- \\
\mathrm{V} \\
\mathrm{V} \\
-\end{array}$ & $\begin{array}{l}- \\
- \\
- \\
- \\
-\end{array}$ & $\begin{array}{l}- \\
\mathrm{V} \\
- \\
-\end{array}$ \\
\hline 胥 & $\begin{array}{l}\text { NP } \\
\text { VP } \\
\text { AdjP } \\
\text { AdvP }\end{array}$ & $\begin{array}{l}- \\
- \\
- \\
-\end{array}$ & $\begin{array}{l}- \\
- \\
- \\
-\end{array}$ & $\begin{array}{l}- \\
- \\
- \\
-\end{array}$ & $\begin{array}{l}- \\
- \\
-\end{array}$ & $\begin{array}{l}- \\
- \\
-\end{array}$ & $\begin{array}{l}- \\
- \\
- \\
-\end{array}$ & $\begin{array}{l}\mathrm{V} \\
- \\
\mathrm{v} \\
-\end{array}$ & $\begin{array}{l}\mathrm{V} \\
- \\
- \\
-\end{array}$ & - \\
\hline \multicolumn{2}{|c|}{ Clause } & - & - & - & - & - & - & - & - & - \\
\hline \multicolumn{2}{|c|}{ Sentence } & - & - & - & - & - & - & $\mathrm{V}$ & - & - \\
\hline
\end{tabular}

c. adaptation of foreign language

There was only one case occurring in one of the letters in Cosmopolitan, as found in jender. The English noun gender was adapted to the Indonesian spelling to represent the sound.

d. combination of English and Indonesian

There was only one case occurring in the use of the Indonesian second person possessive form - $m u$ (your), being attached to the English noun phrase, as seen in beauty guide-mu 
e. unnecessary use of suffix

Similar to the data found in FHM, the Indonesian suffix - an was added to the standard adjective form sabar (patient), making it a non-standard form sabaran

In the case of the non-standard types of $\mathrm{b}$ and $\mathrm{c}$, all the English expressions were borrowed without any modification. In the same way, in terms of patterning, the expressions borrowed from English followed the English patterns, except for one case, i.e. swimsuit special, which was adapted to the Indonesian pattern, where the modifier special followed the head swimsuit, which is different from the English phrase special swimsuit in which the one-word modifier commonly precedes the head.

The features of the non-standard expressions used in both kinds of magazine can be summarized in the following table.

Table 3. Features of Non-Standard Indonesian Expressions

\begin{tabular}{|c|c|c|}
\hline $\begin{array}{ll}\begin{array}{l}\text { Features of } \\
\text { non-standard expressions }\end{array} & \text { Magazine } \\
\end{array}$ & FHM & Cosmopolitan \\
\hline Base + -in & $\sqrt{ }$ & - \\
\hline$d i-+$ base $+-i n$ & $\sqrt{ }$ & - \\
\hline Deletion & $\sqrt{ }$ & - \\
\hline Non-standard term & $\sqrt{ }$ & $\sqrt{ }$ \\
\hline Substitution & $\sqrt{ }$ & - \\
\hline Adaptation of foreign language & - & $\sqrt{ }$ \\
\hline Use of foreign language & $\sqrt{ }$ & $\sqrt{ }$ \\
\hline Combination of Indonesian and English & $\sqrt{ }$ & $\sqrt{ }$ \\
\hline Use of unnecessary suffix & $\sqrt{ }$ & $\sqrt{ }$ \\
\hline
\end{tabular}

From the table, it can be seen that the features of non-standard Indonesian expressions found in FHM were the use of suffix -in, confix di-in, deletion, the use of non-standard or vernacular term (dialect), substitution, the use of foreign language (English), the combination of English and Indonesian, and the use of unnecessary suffix. Some, exactly four, of the features that appeared in FHM were also found in Cosmopolitan. However, there was one type of feature, found in Cosmopolitan, which did not occur in FHM, i.e. adaptation of foreign 
language. The other features of non-standard Indonesian expressions found in Cosmopolitan were the use of non-standard or vernacular term, the use of English, the combination of English and Indonesian, and the use of unnecessary suffix.

It was, thus, revealed that the features of non-standard Indonesian expressions found in FHM were more various than the ones found in Cosmopolitan. From table 1 and 2, it can be seen that the features of nonstandard expressions in FHM appeared in more various linguistic forms than the ones in Cosmopolitan. The non-standard features used in FHM could be found in all parts of speech and function words, noun phrases, adjective phrases, and sentences. On the other hand, in Cosmopolitan, the non-standard expressions were found only in noun, adjective, adverb, noun phrase, adjective phrase and sentence. Non-standard forms of verb, and function word, which occurred in FHM, did not occur in Cosmopolitan. Furthermore, the data also revealed that the features of non-standard expressions occurred in every linguistic form more often in FHM than those in Cosmopolitan. Nevertheless, it was found out that there were no non-standard features in verb phrase, adverbial phrase, and clause either in FHM or in Cosmopolitan.

\section{The Use of Non-Standard Expressions in FHM and Cosmopolitan}

The next question to answer was whether the men really used more non-standard Indonesian expressions than the women. As stated in the previous explanation, the study tried to find out whether the men used more non-standard expressions based on the total number of non-standard sentences used by both gender, compared to the total number of sentences in each of the seven editions of both types magazines, FHM and Cosmopolitan. Sentence units were used to represent the expressions with a basic understanding that a sentence would be non-standard if one or more of its components are non-standard.

The calculation of the number of the non-standard Indonesian sentences and also the total number of the sentences used in the letters in each edition of both kinds of magazines were summed up in table 4 below: 
Table 4. The Frequency of the Use of Non-Standard Expressions by Male and Female Writers

\begin{tabular}{l|cc|cc}
\hline \multicolumn{1}{c|}{ Magazines } & \multicolumn{2}{c|}{ FHM } & \multicolumn{2}{c}{ Cosmopolitan } \\
\cline { 2 - 5 } Editions & $\begin{array}{c}\text { Number of } \\
\text { non- standard } \\
\text { sentences }\end{array}$ & $\begin{array}{c}\text { Number of } \\
\text { sentences }\end{array}$ & $\begin{array}{c}\text { Number of } \\
\text { non-standard } \\
\text { sentences }\end{array}$ & $\begin{array}{c}\text { Number of } \\
\text { sentences }\end{array}$ \\
\hline September 2003 ed. & 8 & 22 & 1 & 6 \\
October 2003 ed. & 21 & 52 & 34 & 17 \\
November 2003 ed. & 14 & 20 & 5 & - \\
December 2003 ed. & 39 & 39 & 26 & 7 \\
January 2004 ed. & 36 & 8 & 4 & 4 \\
February 2004 ed. & 60 & 30 & 26 & 17 \\
March 2004 ed. & 14 & 117 & 3 & 20 \\
\hline \multicolumn{1}{c|}{ TOTAL } & 44 & 252 & 26 & 160 \\
\hline \multicolumn{1}{c|}{$(\%)$} & \multicolumn{2}{|c|}{$46.43 \%$} & \multicolumn{2}{|c}{$12.5 \%$} \\
\hline
\end{tabular}

Using the numbers indicating the total occurrence of non-standard sentences, the percentage of the occurrence of nonstandard sentences in each magazine was calculated. It was done by the following calculation:

Cosmopolitan:

$\frac{\mathrm{n}}{\Sigma \mathrm{n}} \times 100 \%=\frac{20}{160} \times 100 \%=12.5 \%$

FHM:

$\frac{\mathrm{n}}{\Sigma \mathrm{n}} \times 100 \%=\frac{117}{252} \times 100 \%=46.43 \%$

with

$\mathrm{n} \quad=$ numbers of non-standard Indonesian sentences

$\sum \mathrm{N}=$ total numbers of sentences

From the percentage, it can be concluded that the men used more nonstandard Indonesian sentences, which also means that the men used more non-standard Indonesian expressions than the women. The women used only $12.5 \%$ non-standard sentences from the total sentences they produced, while the men, on the other hand, used $46.43 \%$ non-standard sentence from the total sentences they produced in composing their letters. This fact showed that indeed the men used more non-standard expressions than the 
women. What is more, it can be seen that the men writers consistently used more non-standard expressions than the women. This was shown in each monthly edition from September 2003 to March 2004.

The whole findings showed the kinds of non-standard Indonesian expressions used by the male writers of the reader's letters in FHM and those produced by the female writers in Cosmopolitan. There were eight kinds of non-standard Indonesian features that were found in the male magazines, FHM, and five found in the female magazines, Cosmopolitan. Usually, the female and male writers mixed their standard Indonesian with the nonstandard varieties of Indonesian vernacular, Jakartanese or Javanese. In most cases, the foreign language, English, expression was inserted in the Indonesian sentence, either as a separate unit or as a stem to which the Indonesian affix, standard or vernacular, was attached.

The frequency count of the occurrence of non-standard expressions in FHM and Cosmopolitan showed that the male writers used more nonstandard Indonesian expressions more frequently than the female writers. In addition, the male writers used more variety of non-standard features spread over more linguistic forms. The data showed that there were some non-standard features and linguistic forms that could be found in FHM, but were not found in Cosmopolitan. These indicated that the male writers used non-standard expressions more extensively than the female writers.

\section{CONCLUSION}

Some linguists (Lakoff, 1978, Holms, 1992, \& Yule, 1997) argue that men's language is different from women's. In general, they say that men tend to use less formal or non-standard language than women. This has given the inspiration to carry out the study on the non-standard Indonesian expressions used by male and female writers in the Reader's Letters of two different kinds of magazines, respectively designed for male and female readers.

To reveal the kinds of non-standard expressions in terms of linguistic categories and nonstandard features and the frequency of occurrence of the non-standard expressions used by male and female writers, two different kinds of magazines were chosen: the FHM and Cosmopolitan magazines. The data were collected from seven editions of each kind, dated from September 2003 to March 2004. The findings on non-standard features revealed that, totally, there were nine types of non-standard features used 
by the male and female writers in both kinds of magazines: base $+-i n, d i-+$ base $+-i n$, deletion, non-standard term, substitution, foreign language, adaptation of foreign language, combination of English and Indonesian, use of unnecessary suffix, found in both kinds of magazines; eight types found in the FHM magazines and five types found in the Cosmopolitan magazines. Some of the features existed in both kinds of magazine, consisting of the use of non-standard term, use of foreign language, combination of English and Indonesian, and the use of unnecessary suffix. There was one which existed in the Cosmopolitan magazine only, i.e. adaptation of foreign language. On the other hand, there were four kinds which were non existent in the female writers' letters: the use of base $+-i n$, $d i+$ base $+-i n$, deletion and substitution.

In terms of linguistic categories of the non-standard expressions, there were also more kinds of linguistic categories found in the male writers' letters than those found in the female writers' letters in the magazines. In addition, the non-standard feature which was in forms of verb and function word found in FHM were non-existent in Cosmopolitan. All these cases indicated that the male writers employed more kinds of non-standard expressions than the female writers, which was also supported by the results on the frequency count.

Based on the frequency counted on the occurrence of the sentences having non-standard expressions used by the male writers in the seven editions of FHM magazines and the female writers in the equal number of magazines of Cosmopolitan, it was revealed that the male writers consistently used more sentences with non-standard expressions than the female writers. This can be observed that in every edition there were more sentences with non-standard expressions in FHM than in Cosmopolitan. These findings are in line with the statement that men tend to use less formal or non-standard language than women.

\section{REFERENCES}

Alwi, H., Dardjowidjojo, S., Lapoliwa, H., \& Moeliono, A. M. (2003). Tata bahasa baku bahasa Indonesia (ed. 3). [Indonesian standard grammar (3rd ed.)]. Jakarta: Balai Pustaka.

Crystal, D. (1997). A dictionary of linguistics and phonetics (4th ed.). Oxford: Blackwell

Departemen Pendidikan dan Kebudayaan. (1991). Kamus besar bahasa Indonesia (ed. 2). [The Indonesian dictionary (2nd ed.)]. Jakarta: Balai Pustaka. 
Gadsby, A. (2001). Longman: dictionary of contemporary English (3rd ed.). Essex: Pearson Education

Henry, G., T. (1984). Prinsip-prinsip dasar sintaksis. [Syntaxis basic principles] Bandung: Angkasa Bandung.

Holmes, J. (1992). An introduction to sociolinguistics. London: Longman

Hudson, R. A. (1980). Sociolinguistics. Cambridge: Cambridge University Press.

Kellerman, D., F. (1977). The lexicon Webster dictionary (vol. 1). Pennsylvania: The English-Language Institute of America

Kuntjahyaning, S. (2003). The non-standard Indonesian affixes as verb markers used in Asian glitz magazine. Unpublished undergraduate thesis, Petra Christian University, Surabaya.

Macfadyen, H. (1996). The parts of speech. Retrieved February 4, 2004, from http:/www.uottawa.ca/academic/arts/writcent/hypergrammar/partsp.html

Moeljono, M., Koentjahjo, Ardiana, L.I., Tampoebolon, E. S. P., \& Widayati, S. W. (1986). Tingkat tutur bahasa Jawa dialek Banyuwangi (1). [Speech level of Javanese language in Banyuwangi dialect (1)]. Jakarta: Departemen Pendidikan dan Kebudayaan.

Montgomery, M., \& Thomas, H. R. (1994). Language and social life. London: The British Council.

O’Grady, W. Dobrovolsky, M., \& Katamba, F. (1996). Contemporary linguistics: An introduction. London and New York: Longman.

Oka, I.G.N., \& Suparno. (1994). Linguistik umum. [General linguistics]. Jakarta: Departemen Pendidikan dan Kebudayaan.

Riasa, N. (2002). Bahasa ABG dalam cerpen remaja: Implikasi dan pengajarannya bagi siswa/i sekolah menengah di Australia. [Teenagers' language in teenagers' short stories: The implication and the teaching for high school students in Australia]. Retrieved March 25, 2004, from http://www.ialf.edu/bipa/march2002/bahasaabg.html

Tampubolon, D. P. (1978). Pengajaran bahasa dan sastra (vol. 4). [The teaching of language and literature (vol. 4)]. Jakarta: Bhratara Karya Aksara.

Trudgill, P. (1974). Sociolinguistics: Introduction to language and society. London: Cox and Wyman

Yule, G. (1997). The study of language (2nd ed.). New York: Cambridge University Press. 